\title{
THE INFLUENCE OF INFORMATION AND COMMUNICATION TECHNOLOGY ON THE SELLING ACTIVITIES OF THE PROFESSIONAL SALES REPRESENTATIVE
}

\author{
G A P Drotsky \& J W de Jager (TUT); E J North (UP)
}

The application of information and communication technology (ICT) has become a reality in selling in the South African pharmaceutical industry. Low awareness levels exist in the pharmaceutical industry about how the effective use of ICT can contribute to client services and productivity. The effectiveness of ICT in selling depends on the way it is managed and implemented by management and accepted by the salespeople and clients, on how effectively it is applied, and on the influence, it has on the salesperson. A descriptive research design was used to determine whether the introduction of ICT into the selling process has influenced the professional sales representatives' activities in a positive way. The results of this study clearly indicate that pharmaceutical sales representatives, both those appointed before the introduction of ICT and those appointed there after, are not positive about the introduction of ICT into the selling process.

Keywords and phrases: information and communication technology; sales process; sales representatives

\section{INTRODUCTION}

According to Quigg and Wisner (1998:14) and Keillor, Bashaw and Pettijohn (1997:109-120) the introduction of information and communication technology (ICT) into the sales process has transformed the way in which sales representatives carry out the selling activities. The effectiveness of ICT depends on the way it is managed and implemented by management, accepted by salespeople and clients, how effectively it is applied, and the influence it has on the salesperson. Russel and Hoag (2004:102-122) state that although the inner workings of an ICT system may be technically complex, the user interface must be understandable to the individual. Meister (as quoted by Strout, 2000:109) points out that sales managers should understand each salesperson's skills, fears and anxieties to be able to assist them in gaining confidence that ICT will assist them in executing their job more effectively. Taylor (1994:94-99) points out that the application of ICT in the sales process enables sales representatives to carry out their selling activities anywhere, as long as they have access to computers and cellular phones. The pharmaceutical sales representatives in South Africa have been using ICT in detailing pharmaceutical products since October 2001, but the business unit managers are not sure whether the introduction of ICT has influenced the professional sales representatives in a positive way.

\section{OBJECTIVES OF THE STUDY}

The purpose of this paper is to determine whether there are any differences in the way the introduction of ICT influenced the sales activities of professional sales representatives appointed before the introduction of ICT and those of professional sales representatives appointed after the introduction of ICT. 
DROTSKY G A P, DE JAGER J W

\& NORTH E J
The Influence of Information \& Communication

Technology on the Selling Activities of the Professional Sales Representative

\section{DESCRIPTION OF CONCEPTS}

In order to clarify the meaning of certain of the concepts used in this paper the following concepts are explained:

\section{Professional sales representative}

For the purpose of this study, the terms medical representative, salespeople, salespersons, sales force and sales representatives, pharmaceutical representative, professional sales representative will be used as synonyms. Some pharmaceutical companies call the pharmaceutical representatives professional sales representatives.

\section{Information and communication technology}

According to O'Connor \& Calvin (1997:276), information technology (IT) is a generic term encompassing a range of technologies that are used to capture, store, process and transmit information, and include the three main technology groups: hardware, software and telecommunications. From this definition, it is clear that telecommunications are part of information technology. For the purpose of this study, the concept information and communication technology will be referred to as ICT, which is an acronym.

\section{Sales-force automation}

O'Connor \& Calvin (1997:279) and Spiro, Stanton \& Rich (2003:413-414) refer to sales-force automation as the application of a variety of computer and IT applications for improving the productivity of sales representatives. Futrell (2004:31) points out that sales force automation is not a new concept, but that what make it of interest today are the powerful information and communication tools now available. These include portable computers, high-speed modems, cellular and radio data networks that allow wireless communication, and software that allows computers to share information easily with other electronic devices.

\section{LITERATURE REVIEW}

A literature study was conducted and secondary sources were consulted to research the nature of personal selling in general, and to investigate the influence of ICT on the pharmaceutical sales representatives' selling activities. With the introduction of the personal computer in the late 1980s, the way in which business was conducted started to change (Quigg \& Wisner, 1998:114). Keillor, Bashaw and Pettijohn (1997:109-120) agree with Quigg and Wisner (1998:114) that technology has changed the way business is conducted, but add that technology has also increased productivity and has resulted in salespeople being confident when dealing with clients. The technology has caused that sales techniques have to be improved as the salesperson adapts to the continuously changing selling environment (Keillor et al., 1997:109-120). Carter (2002:79-90) agrees with Keillor et al. (1997:109-120) and points out that more than any other agent of change, information technology is transforming the way business works and it is helping organisations to become leaner, smarter, and closer to the customer.

Palmer (1998:4) refers as follows to the application of ICT in the sales process: "If you're in the business of selling, you have no choice but to be in the business of electronic communications." Haler \& Palmer (1999:31) point out that in the past, the salesperson probably maintained customer contact mainly through face-to-face meetings and phone calls, but now the range of contact options have expanded to include fax and electronic mail (e-mail), the Internet and the World-Wide Web, laptops, palmtops and sophisticated contact management software. Visconde (2001:1) agrees with Haler \& Palmer (1999:31) and states that handheld devices, such as 
DROTSKY G A P, DE JAGER J W

\& NORTH E J
The Influence of Information \& Communication

Technology on the Selling Activities of the Professional Sales Representative

personal digital assistants (PDAs) and cellular phones, link salespeople to a central network, via dialup, which gives them those extra minutes a day communication time to synchronise their data and check e-mails. Ahearne and Schillewaert (2000:30-33) state that a salesperson that integrates different ICT tools into his/her sales activities can significantly improve his/her performance. Johnston and Marshall (2003:4) point out that this system benefits the pharmaceutical organisation because it now has the history of the visits to customers on a database when the salespersons resign from the company.

Boshoff (2004:Personal interview) states that the professional sales representatives in the pharmaceutical company use an evidence-based machine (EBM), which is a modified DVD player and plays a pre-prepared presentation on a CD that contains graphics and animations about the pharmaceutical product, to inform and persuade the medical practitioner. Therefore, ICT has a profound effect on almost every facet of sales process and it has the ability to inform and persuade.

Kotler (2003:656) and Strout (2000:109) state that making ICT available to sales representatives enable them to remain in touch and to build long-term relations with their clients, because the ICT influences the client-supplier relationship. It is therefore essential that the professional sales representatives in the pharmaceutical organisation should be trained to use the ICT to solve the client's problems and serve them. Mondy, Premeaux and Young (1998:66) point out that no salesperson can afford to be technologically uneducated, and it is essential that managers should see to it that their sales force is up to date with new technologies and have the essential computer skills to be effective. Boshoff (2004:Personal interview) states that to be efficient and effective the professional sales representatives must technologically educated to apply the ICT to improve communication between themselves and the medical practitioner.

The application of ICT in the sales process increases the efficiency and effectiveness of salespeople to navigate the sales process, by means of its ability to improve communication (Keillor et al., 1997). Boshoff (2004:Personal interview) points out that the application of ICT in the sales process causes that the sales representatives have to work faster, and it demand quicker response from them. The application of ICT in the sales process requires personal innovativeness from the sales representatives. Schillewaert, Ahearne, Frambach \& Moeneart (2000:1-49) define personal innovativeness as "an attitude describing a salesperson's learned and enduring cognitive evaluations, emotional feelings and action tendencies towards a set of objects" (for example, adopting ICT in the selling process). There is practical evidence that many salespeople have a natural resistance to ICT (Campbell as cited by Schilleweart et al., 2000:1-49). Therefore, this resistance or prejudice may influence the value ICT has for professional sales representatives in the selling process.

\section{RESEARCH DESIGN AND METHODOLOGY}

A literature review was conducted and secondary sources were consulted to investigate the nature of personal selling and the influence of ICT on salespeople. Automation of the sales force (the application of ICT in selling) was researched, with emphasis on the technologies used to execute the selling process, or detailing process, as it is known in the pharmaceutical industry. The secondary data used in the study was evaluated to specify the information that was required to reach the research objectives and to enable the researchers to assess the quality of the data and its relationship with the research objectives (Hair, Bush \& Ortinau, 2000:93-95).

In this study, the descriptive research design was used because it is typically guided by an initial hypothesis (Churchill, 2001:126), and because descriptive research design represents a carefully planned and structured research design (Kinnear \& Taylor, 1996:132). Further, it provides a clear statement of the decision problem, specific research objectives and detailed information needs 
DROTSKY G A P, DE JAGER J W

\& NORTH E J
The Influence of Information \& Communication

Technology on the Selling Activities of the Professional Sales Representative

(McDaniel \& Gates, 2002:63; Hair et al., 2000:38). The empirical study was done by means of personal interviews and self-administered questionnaires.

A sample of hundred and one pharmaceutical sales representatives was obtained. Fifty-three of them had been appointed before the introduction of ICT and forty-eight had been appointed after the introduction of ICT as a selling tool. The analysis of the influence of ICT on the selling activities of professional sales representatives appointed before and after the introduction of ICT was done with reference to the secondary objective and the hypothesis that follows. A secondary objective was to determine the influence of information and communication technology on professional sales representatives' selling activities. The following hypothesis was formulated: $\mathrm{Ho}_{1}$ : No significant differences exist between professional sales representatives that were appointed before and those appointed after the introduction of ICT, in terms of the way in which ICT influenced their sales activities. $\mathbf{H a}_{1}$ : Significant differences exist between professional sales representatives that were appointed before and those appointed after the introduction of ICT, in terms of the way in which ICT influenced their sales activities.

The measuring instrument was designed to obtain specific information. Firstly, demographic information of the pharmaceutical sales representatives was obtained. Six sets of data were of interest, namely business unit, gender, age group, appointed before or after the introduction of ICT, position, and regional office. For the purpose of this paper, only data and findings with regard to the sales representatives appointed before or after the introduction of ICT were used. Secondly, the influence of the introduction of ICT into the selling process on the professional sales representative's activities was investigated. A total of thirteen statements about the application of ICT by sales representatives were included in the measuring instrument. Each statement was expressed as an opinion, and respondents were asked to indicate their degree of agreement or disagreement with the statement on a seven-point scale. A strong agreement was associated with a seven-point evaluation, while neither agree nor disagree was associated with a four-point evaluation and a strong disagreement was associated with a one-point evaluation (Malhorta, 2004:296-298).

\section{DATA ANALYSIS}

According to Malhorta (2004:296-298), the Cronbach alpha coefficient assumes equivalence of all items, and its value tends to increase with an increase in the number of scale items. A high Cronbach alpha coefficient would be indicative of high internal consistency in which a set of items measuring a particular characteristic was answered. A Cronbach alpha of 0.8221 was obtained, and this indicates that there is a high degree of internal consistency and that the measuring instrument used for the professional sales representatives in this study is reliable. At first, a factor analysis was applied to the two independent samples, but due to the total sample size of 101 professional sales representatives, the factor analysis failed to give sufficient loadings to identify factors. Therefore, a non-parametric statistical testing method, the Mann-Whitney test, was used for comparing the central tendency of the two independent samples taken from the professional sales representatives. The Mann-Whitney test evaluates the null hypothesis that the two sets of scores were sampled from identical populations and is broader than the null hypothesis tested by the corresponding t- test.

For the purpose of the discussion to follow, the professional sales representatives appointed before the introduction of ICT and professional sales representatives appointed after the introduction of ICT will be referred to as sales representatives appointed before and after the introduction of ICT.

According to Table 1, no significant differences between the way the introduction of ICT in the selling process has influenced the professional sales representatives appointed before the 
DROTSKY G A P, DE JAGER J W

\& NORTH E J
The Influence of Information \& Communication

Technology on the Selling Activities of the Professional Sales Representative

introduction of ICT and the professional sales representatives appointed after the introduction of ICT exists, with regard to all the variables. Therefore, $\mathbf{H o}_{\mathbf{1}}$ is accepted $(\mathbf{p}>\mathbf{0 . 0 5})$ for the variables and the alternative $\mathbf{H a}_{\mathbf{1}}$ is rejected for the variables.

Table 1: The influence of ICT on sales activities

\begin{tabular}{|c|c|c|c|c|c|}
\hline Variable & $\begin{array}{l}\text { Mean } \\
\text { ranks } \\
\text { V104 (1) } \\
\text { appointed } \\
\text { before } \\
\text { introducti } \\
\text { on of ICT }\end{array}$ & $\begin{array}{l}\text { Mean ranks } \\
\text { V104 (2) } \\
\text { appointed } \\
\text { after } \\
\text { introductio } \\
n \text { of ICT }\end{array}$ & $\begin{array}{l}\text { Hypothesis testing } \\
\text { If } p \text {-value }=>0.05 \\
\text { accept } \\
\text { If } p \text {-value }=<0.05 \text { reject }\end{array}$ & $\begin{array}{l}\text { Mean } \\
\text { for at } \\
\text { befor } \\
\text { after } \\
\text { (1) }\end{array}$ & $\begin{array}{l}\text { tistics } \\
\text { nted } \\
\text { d } \\
\text { (2) }\end{array}$ \\
\hline $\begin{array}{l}\text { V35 The use of } \\
\text { information and } \\
\text { communication } \\
\text { technology (ICT) } \\
\text { demands less } \\
\text { effort from me to } \\
\text { do my daily task. }\end{array}$ & 53.22 & 48.55 & $\begin{array}{l}\text { Mann-Whitney U } \\
=1154.500 \\
\text { Asymp. Sig. }=0.412 \\
\text { p-value }=>0.05 \\
\text { Ho }_{1} \text { accepted }\end{array}$ & 4.83 & 4.75 \\
\hline $\begin{array}{l}\text { V36 The use of } \\
\text { ICT results in me } \\
\text { having to work } \\
\text { faster than before. }\end{array}$ & 53.38 & 48.35 & $\begin{array}{l}\text { Mann-Whitney } U= \\
1146.000 \\
\text { Asymp. Sig. }=0.377 \\
\text { p-value }=>0.05 \\
\text { Ho }_{1} \text { accepted }\end{array}$ & 4.66 & 4.50 \\
\hline $\begin{array}{l}\text { V37 The use of } \\
\text { ICT demands a } \\
\text { quicker response } \\
\text { from me. }\end{array}$ & 51.22 & 50.76 & $\begin{array}{l}\text { Mann-Whitney } U= \\
1260.500 \\
\text { Asymp. Sig. }=0.933 \\
\text { p-value }=>0.05 \\
\text { Ho }_{1} \text { accepted }\end{array}$ & 4.28 & 5.13 \\
\hline $\begin{array}{l}\text { V38 The ICT } \\
\text { presentations are } \\
\text { superior to the } \\
\text { standard printed } \\
\text { sales-promotion } \\
\text { aids for detailing } \\
\text { products. }\end{array}$ & 53.39 & 48.36 & $\begin{array}{l}\text { Mann-Whitney } U= \\
1145.500 \\
\text { Asymp. Sig. }=0.384 \\
\text { p-value }=>0.05 \\
\text { Ho }_{1} \text { accepted }\end{array}$ & 4.28 & 3.83 \\
\hline $\begin{array}{l}\text { V39 The ICT } \\
\text { presentation } \\
\text { provides reliable } \\
\text { medical } \\
\text { information when } \\
\text { the professional } \\
\text { sales } \\
\text { representative } \\
\text { details the } \\
\text { pharmaceutical } \\
\text { products. }\end{array}$ & 55.00 & 46.58 & $\begin{array}{l}\text { Mann-Whitney } U= \\
1060.000 \\
\text { Asymp. Sig. }=0.133 \\
\text { p-value }=>0.05 \\
\text { Ho }_{1} \text { accepted }\end{array}$ & 5.43 & 5.00 \\
\hline
\end{tabular}


DROTSKY G A P, DE JAGER J W

\& NORTH E J
The Influence of Information \& Communication Technology on the Selling Activities of the Professional Sales Representative

\begin{tabular}{|c|c|c|c|c|c|}
\hline $\begin{array}{l}\text { V40 The } \\
\text { automation of the } \\
\text { sales force has } \\
\text { increased the } \\
\text { productivity of the } \\
\text { professional sales } \\
\text { representative. }\end{array}$ & 49.35 & 52.82 & $\begin{array}{l}\text { Mann-Whitney } U= \\
1184.500 \\
\text { Asymp. Sig. }=0.543 \\
\text { p-value }=>0.05 \\
\text { Ho }_{1} \text { accepted }\end{array}$ & 4.51 & 4.79 \\
\hline $\begin{array}{l}\text { V41 The } \\
\text { automation of the } \\
\text { sales force } \\
\text { provides more } \\
\text { reliable information } \\
\text { for detailing } \\
\text { pharmaceutical } \\
\text { products. }\end{array}$ & 48.55 & 53.71 & $\begin{array}{l}\text { Mann-Whitney } U= \\
1142.000 \\
\text { Asymp. Sig. }=0.368 \\
\text { p-value = >0.05 } \\
\text { Ho }_{1} \text { accepted }\end{array}$ & 4.30 & 4.67 \\
\hline $\begin{array}{l}\text { V42 The } \\
\text { professional sales } \\
\text { representative has } \\
\text { fully accepted the } \\
\text { sales-force } \\
\text { automation } \\
\text { process. }\end{array}$ & 52.41 & 49.45 & $\begin{array}{l}\text { Mann-Whitney } U= \\
1197.500 \\
\text { Asymp. Sig. = } 0.606 \\
\text { p-value }=>0.05 \\
\text { Ho }_{1} \text { accepted }\end{array}$ & 4.53 & 4.40 \\
\hline $\begin{array}{l}\text { V43 ICT enables } \\
\text { the professional } \\
\text { sales } \\
\text { representative to } \\
\text { change scheduled } \\
\text { appointments } \\
\text { during a working } \\
\text { day. }\end{array}$ & 49.88 & 52.24 & $\begin{array}{l}\text { Mann-Whitney } U= \\
1212.500 \\
\text { Asymp. Sig. }=0.678 \\
\text { p-value }=>0.05 \\
\text { Ho }_{1} \text { accepted }\end{array}$ & 4.28 & 4.50 \\
\hline $\begin{array}{l}\text { V44 The use of the } \\
\text { database on ICT to } \\
\text { store and extract } \\
\text { data has } \\
\text { decreased my } \\
\text { productivity. }\end{array}$ & 49.85 & 52.27 & $\begin{array}{l}\text { Mann-Whitney } U= \\
1211.000 \\
\text { Asymp. Sig. }=0.665 \\
\text { p-value }=>0.05 \\
\text { Ho }_{1} \text { accepted }\end{array}$ & 2.74 & 2.73 \\
\hline $\begin{array}{l}\text { V45 ICT } \\
\text { decreases the time } \\
\text { it takes me to } \\
\text { complete my sales } \\
\text { reports. }\end{array}$ & 50.87 & 51.15 & $\begin{array}{l}\text { Mann-Whitney } U= \\
1265.000 \\
\text { Asymp. Sig. }=0.961 \\
\text { p-value = >0.05 } \\
\text { Ho }_{1} \text { accepted }\end{array}$ & 4.28 & 4.44 \\
\hline $\begin{array}{l}\text { V46 I am } \\
\text { experiencing that } \\
\text { by using ICT I am } \\
\text { given more time by } \\
\text { the medical } \\
\text { practitioners. }\end{array}$ & 49.87 & 52.25 & $\begin{array}{l}\text { Mann-Whitney } U= \\
1212.000 \\
\text { Asymp. Sig. }=0.675 \\
\text { p-value }=>0.05 \\
\text { Ho }_{1} \text { accepted }\end{array}$ & 2.74 & 2.90 \\
\hline
\end{tabular}


DROTSKY G A P, DE JAGER J W

\& NORTH E J
The Influence of Information \& Communication

Technology on the Selling Activities of the Professional Sales Representative

\begin{tabular}{|c|c|c|c|c|c|}
\hline $\begin{array}{l}\text { V47 I am } \\
\text { experiencing that } \\
\text { by using ICT I am } \\
\text { able to make more } \\
\text { sales calls during a } \\
\text { week. }\end{array}$ & 46.89 & 55.64 & $\begin{array}{l}\text { Mann-Whitney U } \\
=1054.000 \\
\text { Asymp. Sig. }=0.129 \\
\text { p-value }=>0.05 \\
\text { Ho }_{1} \text { accepted }\end{array}$ & 2.58 & 3.02 \\
\hline \multicolumn{6}{|c|}{$\begin{array}{l}\text { Abbreviations } \\
\text { V = Variable } \\
\text { Asymp. Sig. = Asymptotically Significance (2-tailed) } \\
\text { Mann-Whitney U = Mann-Whitney U Test Statistics for Grouping Variable: V104 } \\
\text { V104 (1) = Representatives appointed before introduction of ICT } \\
\text { V104 (2) = Representatives appointed after introduction of ICT }\end{array}$} \\
\hline
\end{tabular}

The professional sales representatives experience the use of ICT as a selling tool in the sales process as follows:

V35 - The professional sales representatives appointed before and after the introduction of ICT neither agree nor disagree that ICT demands less effort from them to do their daily task, but neither agreeing nor disagreeing may be due to ignorance or a lack of experience and/or knowledge, through not using ICT.

V36 - The professional sales representatives appointed before and after the introduction of ICT neither agree nor disagree that ICT results in them having to work faster than before, due to a lack of experience and/or knowledge through not using ICT. Neither agreeing nor disagreeing may be due to ignorance or a lack of experience and/or knowledge, through not using ICT.

V37 - The professional sales representatives appointed before the introduction of ICT neither agree nor disagree that ICT demands quicker response from them, but neither agreeing nor disagreeing may be due to ignorance or a lack of experience and/or knowledge, through not using ICT.

The professional sales representatives appointed after the introduction of ICT slightly agree that ICT demands a quicker response from them, and therefore they slightly perceive that ICT demands a quicker response from them.

V38 - The professional sales representatives appointed before the introduction of ICT neither agree nor disagree that the ICT presentations are superior to the standard printed salespromotion aids for detailing products, but neither agreeing nor disagreeing may be due to ignorance or a lack of experience and/or knowledge, through not using ICT.

The professional sales representatives appointed after the introduction of ICT slightly disagree and therefore they do not have strong perceptions that the ICT presentations are superior to the standard printed sales-promotion aids for detailing products.

V39 - The professional sales representatives appointed before and after the introduction of ICT slightly agree that the ICT presentation provides reliable medical information when the professional sales representative details the pharmaceutical products. Therefore, the ICT presentation enables them to be more productive when they detail pharmaceutical products.

V40 - The professional sales representatives appointed before and after the introduction of ICT neither agree nor disagree that the automation of the sales force has enabled them to be more productive, but neither agreeing nor disagreeing may be due to ignorance or a lack of experience and/or knowledge, through not using ICT. 
DROTSKY G A P, DE JAGER J W

\& NORTH E J
The Influence of Information \& Communication

Technology on the Selling Activities of the Professional Sales Representative

V41 - The professional sales representatives appointed before and after the introduction of ICT neither agree nor disagree that the automation of the sales force provides more reliable information for detailing pharmaceutical products, but neither agreeing nor disagreeing may be due to ignorance or a lack of experience and/or knowledge, through not using ICT.

V42 - The professional sales representatives appointed before and after the introduction of ICT neither agree nor disagree that they have fully accepted the sales-force automation process, but neither agreeing nor disagreeing may be due to ignorance or a lack of experience and/or knowledge, through not using ICT.

V43 - The professional sales representatives appointed before and after the introduction of ICT neither agree nor disagree that the ICT enables them to change scheduled appointments during a working day, but neither agreeing nor disagreeing may be due to ignorance or a lack of experience and/or knowledge, through not using ICT.

V44 - The professional sales representatives appointed before and after the introduction of ICT disagree, and therefore the use of the database on ICT to store and extract data has not decreased their productivity. Therefore the database assists them to be more productive.

V45 - The professional sales representatives appointed before and after the introduction of ICT neither agree nor disagree that ICT decreases the time it takes them to complete their sales reports, but neither agreeing nor disagreeing may be due to ignorance or a lack of experience and/or knowledge, through not using ICT.

V46 - The professional sales representatives appointed before and after the introduction of ICT disagree and therefore they perceive that by using ICT they do not have more time to spend with medical practitioners.

V47 - The professional sales representatives appointed before the introduction of ICT disagree and therefore they have strong perceptions that by using the ICT they are not able to make more sales calls during a week.

The professional sales representatives appointed after the introduction of ICT slightly disagree and therefore they do not have strong perceptions that by using the ICT they are not able to make more sales calls during a week.

Summarising Table 1 gives an overall picture of the way in which the introduction of ICT into the selling process influenced the selling activities of the representatives when using ICT to detail pharmaceutical products. In the case of nine out of thirteen of the variables, the professional sales representatives neither agree nor disagree. That indicates that they are ignorant about the value of ICT as a selling tool. Possible reasons why the sales representatives neither agree or disagree could be that the personalities of the sales representatives are such that they are not much concerned about applying ICT to the selling process, or it could be that they are ignorant because they prefer not to use ICT in the selling process, or it could be due to lack of knowledge and/or experience, through not using the ICT as a selling tool, as the management expects them to do. It appears that they have a natural resistance or prejudice against the use of ICT in the selling process, and that could influence the value of ICT to the professional sales representatives in the selling process.

\section{FINDINGS}

A condensed interpretation of all the findings is that the ICT demand less effort from the professional sales representatives to do their daily sales task; it provides a little bit more reliable 
DROTSKY G A P, DE JAGER J W

\& NORTH E J
The Influence of Information \& Communication

Technology on the Selling Activities of the Professional Sales Representative

information for detailing pharmaceutical products; it has enabled them to be slightly more productive; it has not decreased their productivity; it slightly decreased the time it takes them to complete their sales reports; and it provides reliable medical information when they detail the pharmaceutical products.

On the other hand, the medical practitioners do not award them more time to detail products; they have to work a little faster than before; and they tend to be ignorant because they have not fully accepted the sales force automation process. The sales representatives tend to be ignorant about the use of ICT because it appears as if they have a natural resistance or prejudice against the use of ICT in the selling process because they did not buy into the sales force automation process, and that may influence the professional sales representative's value for ICT in the sales process.

Sales representative appointed before the introduction of ICT differ from those appointed after the introduction of ICT. Those appointed before perceive that the ICT are slightly superior to the standard printed sales promotion aids; and that they are not able to make more sales calls during a week Those appointed after the introduction of ICT perceive the ICT as slightly not superior to the standard printed sales promotion aids; and that they are not sure if they will be able to make more sales calls during a week.

\section{RECOMMENDATIONS}

The following are recommended:

- Management should develop training programmes to change the negative attitudes of all marketing and sales staff towards ICT into positive attitudes.

- All managers and supervisors should be retrained to be able to assist and explain the application of ICT to their subordinates.

- All representatives should be retrained to use ICT effectively in all facets of the sales process.

- Further research should be done to establish the underlying reasons for the sales representatives' negativity, as well as their reasons for not using ICT in the selling process.

\section{REFERENCES}

Ahearne, M. \& Schillewaert, N. 2000. The effect of information technology on salesperson performance. [Online]. Available from: http://www.ebru.psu.edu. [Accessed: 25/11/2004]

Boshoff R. 2004. Personal interview. Aventis Pharma (Pty) Ltd, Midrand, Gauteng, South Africa.

Carter T. 2002. Technology and the Sales Force: Amach, Inc. Journal of Hospital Marketing and Public Relations, 14 (1): 79-90.

Churchill GA (Jr.). 2001. Basic Marketing Research. 4th Ed. Australia: South-Western.

Hair JF (Jr.), Bush RP and Ortinau DJ. 2000. Marketing Research - A Practical Approach for the New Millennium. Boston: Irwin McGraw Hill.

Haler C and Palmer G. 1999. Putting Technology to Work in Managing Customer Relationships. The SA Journal of Marketing and Sales, 5(4): 30-31. 
DROTSKY G A P, DE JAGER J W

\& NORTH E J
The Influence of Information \& Communication

Technology on the Selling Activities of the Professional Sales Representative

Johnston MW and Marshall GW. 2003. Churchill/Ford/Walker's Sales Force Management. $7^{\text {th }}$ Ed. Boston: McGraw-Hill Irwin.

Keillor BD, Bashaw RE and Pettijohn CE. 1997. Sales Force Automation Issues Prior to Implementation: the Relationship between Attitudes toward Technology, Experience and Productivity. Journal of Business and Industrial Marketing, Summer 12(3-4): 209-220 [Online] Available from: <http//web7.../purl=rc1_GBIM_0_A20057206\&dyn=3!xrn_2_0_A20057206? sw_aep=tp_it $>$ [Accessed: 2000/10/08].

Kinnear TC and Taylor JR. 1996. Marketing Research - An Applied Approach. $5^{\text {th }}$ Ed. New York: McGraw-Hill Inc.

Kotler, P. 2003. Marketing Management. Eleventh Edition. New Jersey: Prentice Hall.

Malhorta NK. 2004. Marketing Research - An Applied Orientation. $4^{\text {th }}$ Ed. New Jersey: Pearson Prentice Hall.

McDaniel C (Jr) and Gates R. 2002. Marketing Research - The Impact of the Internet. United States: South-Western.

Mondy RW, Premeaux SR and Young JR. 1998. Personal Selling - Function, Theory and Practice. $4^{\text {th }}$ Ed. Houston: Dame Publications Inc.

Palmer P. 1998. On-line shopping - Will Cybermalls Reshape the Retail Industry? The SA Journal of Marketing and Sales, 4(5): 3-6.

Quigg B and Wisner B. 1998. Selling the Right Way. New Jersey: Prentice-Hall.

Russel DM and Hoag AM. 2004. People and Information Technology in the supply chain - Social and organizational influences on adoption. International Journal of Physical Distribution and Logistics Management, 34(2): 102-122.

Schillewaert, N., Ahearne, M.J., Frambach, R.T., \& Moeneart, R. K. 2000. The acceptance of information technology in the sales force. [Online]. Available from: http//www.smeal.psu.edu/ebre/ publications/res_papers/2000-07.html. [Accessed: 25/11/2004]

Strout E. 2000. Are Your Salespeople Tech Savvy? Sales and Marketing Management, 152(7):109 [Online] Available from: <http//web7.infotrac.lond.../purl=rc1_GBIM_0_A63668025 \&dyn=13!ar_fmt?sw_aep=tp_it> [Accessed: 2000/10/08].

Taylor TC. 1994. Going Mobile. Sales and Marketing Management [Online] Available from:<http://infotrac.london.gale.../purl=rc1_GBIM_0_A15230273\&dyn56!ar_fmt?sw_aep=tp_it.> [Accessed: 2002/07/05].

Visconde H. 2001. iForce Hero [Online] Available from: http:// www.sunmicrosystems.com [Accessed: 2004/11/25]. 